\title{
The issues of the homosexual with regards to reproductive health*
}

\section{Problemy par homoseksualnych w odniesieniu do zdrowia reprodukcyjnego*}

\author{
Agnieszka Licow ${ }^{1,2} \bowtie$ \\ ${ }^{1}$ Pomorski Uniwersytet Medyczny w Szczecinie, Klinika Ginekologii, Endokrynologii i Onkologii Ginekologicznej, ul. Unii Lubelskiej 1, 71-252 Szczecin \\ Pomeranian Medical University in Szczecin, Department of Gynecology, Endocrinology and Gynecological Oncology \\ 2Samodzielny Specjalistyczny Zakład Opieki Zdrowotnej „Zdroje”, Oddział Noworodków, Patologii i Intensywnej Terapii, ul. Mączna 4, 70-780 Szczecin \\ Independent Specialized Health Care Center „Zdroje”, Neonatal Unit, Pathology and Intensive Care \\ ৫alicow@interia.pl
}

\begin{abstract}
Introduction: The aim of the study was to analyze the problems of homosexual couples with regard to reproductive health, with particular emphasis on the sex and age of the subjects.

Materials and methods: The study covered a group of 100 people who described their sexual orientation as homosexual. Participation in the survey was anonymous and voluntary. The research was carried out between November 2011 and March 2012 in Poland. The research method used in this study was the diagnostic survey and the research tool employed was the survey questionnaire.

Results: In research $75 \%$ of respondents stated that homosexual orientation is an inborn characteristic; $78 \%$ of respondents had "come out" with their homosexual orientation; $84 \%$ of respondents
\end{abstract}

were in favor of the legalization of partnership in Poland; $54 \%$ of respondents said they did not see any contraindications for a couple of the same sex to raise a child, and 38.8\% planned to adopt a child should it be legally possible. The presence of homophobia in Polish society was confirmed by $75 \%$ of respondents.

Conclusions: Most lesbian and gay people define their sexual orientation before the age of 18 . Acceptance and empathy are the most common reactions to the "coming out" of people with homosexual orientations. Homosexual people accept their sexual orientation. Lesbian and gay people are aware of sexually transmitted diseases. Homosexuals support the legalization of civil unions in Poland.

Keywords: homosexual; homosexuality; reproductive health; homophobia; sexual orientation.

\begin{abstract}
ABSTRAKT
Wstęp: Celem pracy była analiza problemów par homoseksualnych w odniesieniu do zdrowia reprodukcyjnego, ze szczególnym uwzględnieniem płci i wieku badanych.

Materiały i metody: Populację badaną stanowiło 100 osób, które określiły swoją orientację jako homoseksualną. Udział w badaniu był anonimowy i dobrowolny. Badania przeprowadzono w okresie od listopada 2011 do marca 2012 r. na terenie Polski. Metodą badawczą wykorzystaną w pracy był sondaż diagnostyczny, a narzędziem badawczym kwestionariusz ankiety.

Wyniki: W badaniu 75\% ankietowanych stwierdziło, że orientacja homoseksualna jest cechą wrodzoną; $78 \%$ badanych ujawniło swoją orientację homoseksualną; $84 \%$ opowiedziało się za legalizacją związków partnerskich w Polsce; 54\% respondentów
\end{abstract}

uznało, że nie widzi przeciwwskazań, aby para osób tej samej płci wychowywała dziecko, a 38,8\% planowało adopcję dziecka, gdyby pojawiła się taka możliwość prawna. Występowanie zjawiska homofobii w polskim społeczeństwie potwierdziło $75 \%$ ankietowanych.

Wnioski: Większość lesbijek i gejów określa swoją orientację seksualną przed 18. r.ż., a akceptacja i zrozumienie są najczęstszą reakcją na ujawnienie się. Osoby homoseksualne akceptują swoją orientację seksualną i są świadome chorób przenoszonych drogą płciową. Osoby orientacji homoseksualnej popierają legalizację związków partnerskich w Polsce.

Słowa kluczowe: homoseksualizm; homoseksualność; zdrowie reprodukcyjne; homofobia; orientacja seksualna.

\section{INTRODUCTION}

Homosexuality - what exactly is it? What do we know about it? Do we tolerate people of a different than heterosexual orientation among us? Is homosexuality still a taboo topic?

Alongside the development of sexology there has been an increase in society's consciousness about the existence of other, different sexual orientations. It is a fact that cultural tendency

\section{WSTĘP}

Homoseksualizm - czym właściwie jest? Co o nim wiemy? Czy tolerujemy wśród nas obecność osób innej orientacji niż heteroseksualna? Czy nadal homoseksualizm jest tematem tabu?

Wraz z postępem nauki w zakresie seksualności człowieka wzrasta świadomość społeczeństwa na temat istnienia różnych orientacji seksualnych. Faktem jest, że tendencja kulturowa

\footnotetext{
* Article based on Master's thesis written at the Department of Obstetrics and Gynecology of Pomeranian Medical University in Szczecin. Promotion: D.M.Sc. Sławomir Szymański. The original typescript includes: 113 pages, 58 tables, 10 figures and 59 references.

* Artykuł na podstawie pracy magisterskiej napisanej w Zakładzie Pielęgniarstwa Położniczo-Ginekologicznego na Wydziale Nauk o Zdrowiu Pomorskiego Uniwersytetu Medycznego w Szczecinie. Promotor: dr n. med. Sławomir Szymański. Oryginał obejmuje: 113 stron, 58 tabel, 10 rycin oraz 59 pozycji piśmiennictwa.
} 
reduces interpersonal relations to heterosexuality and nonheterosexual identities are often portrayed as examples of deviancy [1].

For several years, we have been witnessing more and more discussions about homosexual couples, related to their rights, their current situation, their health, the violence they experience from the environment in which they grew up, acts of intolerance, legalization of same-sex relationships, or the right to adopt a child. However, quite often most of these efforts do not yield any results, as discussions about these issues are dominated by strong emotions and prejudices [2].

There are many reasons for such a state of affairs. Could it be that we know too little about the matter? Maybe the society in which we all grew up does not allow people "other" than ourselves to belong? Maybe it is fear of reactions from the immediate environment? A significant part of society does not want to become acquainted with minorities because it fears them, does not understand them, and prefers to stay as far away from them as is possible. Poland as a nation stands in the middle of tolerance and rejection.

According to the definition by the WHO, reproductive health is a state of complete physical, mental, and social well-being. It is not only a lack of illness or powerlessness. The term refers to processes, reproductive functions, and the reproductive system at all stages of human life. The right to reproductive health includes, among others, the right to freedom, security, family planning, privacy, and the right to change customs and traditions which violate the well-being of sexual minorities. This also includes the right to education, including sex education based on sound scientific knowledge [3].

This begs a question at this point: do we, as a society, violate these rights in regards to people of homosexual orientation through the prism of their sexuality?

This research paper addresses the problems of homosexual relationships with regards to reproductive health, their life in society, rights and the possibility of family planning, personal fulfillment, and the right of the individual to pursue individual development or unrestricted expression of love.

The purpose of this research was to analyse the problems of homosexual couples with regards to reproductive health, with an emphasis on the sex and age of the interviewed persons.

\section{MATERIALS AND METHODS}

The research method used in this paper was the diagnostic survey and the research tool employed was the survey questionnaire. It was composed of 24 questions and was prepared by the author of the research paper herself. Analysis especially took into account the sex and age of the respondents.

The study covered a group of 100 people who described their sexual orientation as homosexual. The respondents gave oral permission to perform the survey. Participation in the survey was anonymous and voluntary. The research was carried out in the time-span from November 2011 to March 2012 in the territory of Poland. sprowadza relacje międzyludzkie do heteroseksualności, a tożsamości nieheteroseksualne często postrzegane są w kategoriach dewiacji [1].

Od kilku lat obserwujemy coraz częstsze dyskusje na temat par homoseksualnych. Dotyczą one ich praw, sytuacji, w jakiej się znajdują, zdrowia, przemocy ze strony otoczenia, aktów nietolerancji, legalizacji związków czy też prawa do adopcji. Jednak często te dyskusje nie przynoszą odmiany, gdyż argumenty zdominowane są przez silne emocje i uprzedzenia [2].

Powodów tego stanu jest bardzo wiele. Może społeczeństwo zbyt mało wie na temat homoseksualizmu? Może jego członkowie nie pozwalają na dopuszczenie do siebie osób „innych” niż oni sami, może boją się reakcji najbliższego otoczenia? Większość społeczeństwa nie chce poznawać mniejszości, ponieważ się ich obawia, nie rozumie, woli trzymać się od nich z daleka. Polacy wahają się między tolerancją a odrzuceniem.

Zdrowie reprodukcyjne, wg definicji przyjętej przez Światową Organizację Zdrowia (WHO), jest stanem całkowitego fizycznego, psychicznego i społecznego dobrego samopoczucia, a nie tylko braku choroby lub niemocy. Pojęcie odnosi się do procesów, funkcji reprodukcyjnych i układu rozrodczego na wszystkich etapach życia człowieka. Prawo do zdrowia reprodukcyjnego obejmuje m.in. prawo do wolności, bezpieczeństwa, planowania rodziny, prywatności, zmiany obyczajów i tradycji pogwałcających mniejszości seksualne, do edukacji, w tym edukacji seksualnej opartej na rzetelnej wiedzy naukowej [3]. Nasuwa się pytanie, czy społeczeństwo nie pogwałca tych praw w stosunku do osób orientacji homoseksualnej przez pryzmat ich seksualności?

W artykule poruszono problemy związków homoseksualnych w odniesieniu do zdrowia reprodukcyjnego, ich życia w społeczeństwie, praw oraz możliwości planowania rodziny, realizowania się w życiu osobistym oraz prawa jednostki do akceptacji indywidualnego rozwoju czy nieskrępowanego wyrażania miłości.

Celem była analiza problemów par homoseksualnych w odniesieniu do zdrowia reprodukcyjnego, ze szczególnym uwzględnieniem płci i wieku badanych.

\section{MATERIAtY I METODY}

Metodą badawczą wykorzystaną w pracy był sondaż diagnostyczny, a narzędziem badawczym kwestionariusz ankiety. Zawierał on 24 pytania, a sporządzony został samodzielnie przez autora. W analizie uwzględniono w szczególności płeć oraz wiek badanych.

Badaniem objęto grupę 100 osób, które określiły swoją orientację jako homoseksualną. Respondenci wyrazili ustną zgodę na przeprowadzenie badań, w których udział był anonimowy i dobrowolny. Sondaż przeprowadzono w okresie od listopada 2011 do marca 2012 r. na terenie Polski.

Kobiety stanowiły 51\% ankietowanych, mężczyźni $49 \%$. W wieku 18-25 lat było 53\% respondentów, zaś powyżej 25. r.ż. plasowało się 47\% badanych. Wśród 100 ankietowanych $25 \%$ pochodziło z terenów wiejskich, $29 \%$ z miasta $<100000$, 
Women made up $51 \%$ of the persons interviewed, the men $49 \%$. Between the age of 18 and 25 was $53 \%$ of the respondents, while people older than 25 years of age made up $47 \%$ of the total people interviewed. Among the 100 interviewed people, $25 \%$ of them came from rural areas, $29 \%$ from the urban areas with population $<100000$, and $46 \%$ from urban areas with population $>100000.6 \%$ of the respondents had only elementary school level education, $7 \%$ had trade or vocational school level education, $49 \%$ high school level education, and 38\% had higher, university level education/degree.

The Statistica 10 software was used for statistical analysis of the gathered data. Pearson's chi-squared independence test was used to calculate the relationship between gender, age, and the selected questions, due to the qualitative nature of the variables. Statistical significance was determined when $\mathrm{p}<0.05$.

\section{RESULTS}

Among 100 respondents 1 person stated that homosexual orientation is an illness, $75 \%$ that it is an inherited trait, $18.5 \%$ considered it to be an acquired trait, and $5.6 \%$ chose the answer "other".

Before the age of $1868 \%$ of respondents defined their sexual orientation as homosexual, $19 \%$ did so between the ages of 18 and 25 , and $13 \%$ did so above the age of 25 .

Between the ages of 18 and $2579.2 \%$ of respondents had defined their orientation as homosexual before the age of 18 , $18.9 \%$ between the age of 18 and 25 , and $1.9 \%$ above the age of 25 . Over 25 years of age $55.3 \%$ of respondents had defined their sexual orientation before the age of $18,19.1 \%$ between the ages of 18 and 25 , and $25.5 \%$ after the age of 25 . The differences were statistically significant (Tab. 1).

Among woman $86.3 \%$ of the interviewed accept their sexual orientation, $5.9 \%$ do not, while $7.8 \%$ of the interviewed women expressed indecisiveness on this topic. Among men $83.7 \%$ of the interviewed accept their sexual orientation, $8.2 \%$ do not accept it, and $8.2 \%$ of the men interviewed said they were undecided in this matter. The differences were not statistically significant.

In a group of respondents $78 \%$ had revealed their homosexual orientation to society, while $22 \%$ did not disclose it. The disclosure of one's homosexual orientation, depending on age and sex, was not statistically significant.

TABLE 1. The age of recognizing one's homosexual orientation by respondents of different age groups

TABELA 1. Wiek określenia swojej orientacji jako homoseksualnej przez respondentów w różnych grupach wiekowych

\begin{tabular}{lcccccc} 
& \multicolumn{2}{c}{$\begin{array}{c}\text { Age 18-25 / } \\
\text { 18-25 lat }\end{array}$} & \multicolumn{2}{c}{$\begin{array}{c}\text { Age >25 / } \\
>25 \text { lat }\end{array}$} & \multicolumn{2}{c}{ Total/Ogółem } \\
\cline { 2 - 8 } & $\mathbf{n}$ & $\%$ & $\mathbf{n}$ & $\%$ & $\mathbf{n}$ & $\%$ \\
\hline Before 18 & 42 & 79.2 & 26 & 55.3 & 68 & 68.0 \\
\hline Between 18 and 25 & 10 & 18.9 & 9 & 19.1 & 19 & 19.0 \\
\hline Above 25 & 1 & 1.9 & 12 & 25.5 & 13 & 13.0 \\
\hline Total & 53 & 100.0 & 47 & 100.0 & 100 & 100.0 \\
\hline
\end{tabular}

* test $X^{2}(p=0.002), X=$ age of respondents, $Y=$ age of recognition of homosexuality a $46 \%$ z miasta $>100$ 000. Wykształcenie podstawowe miało $6 \%$ respondentów, $7 \%$ zawodowe, $49 \%$ średnie, a 38\% wyższe.

Do analizy statystycznej pozyskanych danych wykorzystano program Statistica 10. Do obliczenia zależności między płcią i wiekiem a wybranymi pytaniami zastosowano test niezależności $\chi^{2}$ Pearsona ze względu na jakościowy charakter zmiennych. Na poziomie istotności 0,05 badano czy istnieje istotna zależność między badanymi zmiennymi. Istotność statystyczna miała miejsce, gdy $\mathrm{p}<0,05$.

\section{WYNIKI}

Wśród 100 ankietowanych 1 osoba odpowiedziała, że orientacja homoseksualna jest chorobą, 75\% - że jest cechą wrodzoną, 18,5\% określiło ją jako nabytą, 5,6\% zaznaczyło odpowiedź „inne”.

W grupie ankietowanych $68 \%$ określiło swoją orientację jako homoseksualną przed 18. r.ż., 19\% między 18. a 25. r.ż., natomiast $13 \% \mathrm{w}$ wieku powyżej 25 lat.

Ankietowani w wieku 18-25 lat określili swoją orientację jako homoseksualną przed 18. r.ż., 18,9\% między 18. a 25. r.ż., 1,9\% w wieku powyżej 25 lat.

W grupie badanych po 25 . r.ż. 55,3\% określiło swoją orientację seksualną przed 18. r.ż., 19,1\% między 18. a 25. r.ż., natomiast 25,5\% po 25. r.ż. Różnice były istotne statystycznie (tab. 1).

Wśród ankietowanych kobiet 86,3\% akceptuje swoją orientację seksualną, 5,9\% nie akceptuje, zaś 7,8\% wyraziło swoje niezdecydowanie w tym temacie. Pośród mężczyzn 83,7\% akceptuje swoją orientację seksualną, 8,2\% jej nie akceptuje i również tylu badanych odpowiedziało, że są niezdecydowani. Różnice nie były istotne statystycznie.

Na pytanie o ujawnienie orientacji seksualnej w społeczeństwie $78 \%$ ankietowanych odpowiedziało twierdząco, zaś $22 \%$ udzieliło informacji, że jej nie ujawniło. Odpowiedzi w zależności od wieku i płci nie były istotne statystycznie.

W przypadku pytania o grupę, przed którą doszło do ujawnienia, 33,9\% ankietowanych wskazało przyjaciół, 27,2\% znajomych, $22,8 \%$ rodzinę, 16,1\% pracodawców i współpracowników. Zależność między płcią i wiekiem nie była istotna statystycznie (tab. 2).

Najczęstszą reakcją ludzi na ujawnienie im orientacji homoseksualnej przez ankietowane kobiety była akceptacja - 33,3\%. Następnie kolejno: zrozumienie $-32,4 \%$, rozczarowanie 14,4\%, złość - 12,6\% i odrzucenie - 7,2\%. Mężczyźni udzielili

TABLE 2. Persons to whom the respondents have revealed their homosexual orientation

TABELA 2. Osoby, którym respondenci ujawnili swoją orientację homoseksualną

\begin{tabular}{lcc} 
& $\mathbf{n}$ & $\%$ \\
\hline Friends & 86 & 33.9 \\
\hline Acquaintances & 69 & 27.2 \\
\hline Family & 58 & 22.8 \\
\hline Employer(s) and co-workers & 41 & 16.1 \\
\hline Total & 254 & 100.0 \\
\hline
\end{tabular}


Among respondents $33.9 \%$ revealed their sexual orientation to friends, $27.2 \%$ to acquaintances, $22.8 \%$ to their families, $16.1 \%$ to employers and co-workers. The gender-age relationship was not statistically significant (Tab. 2).

The most frequent reaction of people to the interviewed women's "coming out" was acceptance $-33.3 \%$. Then, in turn: understanding $-32.4 \%$, disappointment $-14.4 \%$, anger $-12.6 \%$, and rejection $-7.2 \%$. The following answers were provided by men: acceptance $-36.1 \%$, understanding $-35.2 \%$, disappointment $-13 \%$, anger $-8.3 \%$, rejection $-7.4 \%$. The differences were not statistically significant.

In a group of respondents $80.6 \%$ stated that their relatives did not "turn away" from them when they heard about their homosexual orientation, while $19.4 \%$ indicated the opposite.

Most often relatives "turned away" from people over the age of $25-29.5 \%$ compared to $10.2 \%$ of relatives who turned away from people aged $18-25$. Thus $89.8 \%$ of respondents between the ages of 18 and 25 and $70.5 \%$ above the age of 25 acknowledged that relatives did not "turn away" from them after revealing their homosexual orientation. The differences were statistically significant (Tab. 3).

Among the respondents between the ages of 18 and $2569.8 \%$ had stated that even if it would be possible to change their homosexual orientation to heterosexual, they would not make such a choice, $3.8 \%$ would make such a change, whereas $26.4 \%$ responded "I don't know". In the group of respondents over the age of $2548.9 \%$ would not take advantage of the opportunity to change their sexual orientation, $19.1 \%$ answered in the affirmative, while 31.9\% stated "I don't know". The differences were statistically significant (Tab. 4).

Among respondents 57.1\% answered that they had sexual contact with the opposite sex, while $42.9 \%$ answered "no". Differences in sex and age were not statistically significant (Tab. 5).

Respondents indicated that they most often met other homosexual people via the Internet $-31.1 \%$. Other popular methods were through friends $-28.8 \%$, or at a pub $-25.1 \%$. The rarest responses were through classified ads $-8.2 \%$ and other $-6.7 \%$. Respondents included the workplace and the train station in the scope of the "other" answer. Differences in age and sex were not statistically significant.

Among the respondents $55 \%$ replied that there is no need for the employer to know about the homosexual orientation of his/her employees, $25 \%$ of respondents had no opinion, while

TABLE 3. The occurrence of a negative reaction to people, of various age ranges, who revealed their sexual orientation

TABELA 3. Wystąpienie negatywnej reakcji u osób, którym badani w różnych przedziałach wiekowych ujawnili swoją orientację seksualną

\begin{tabular}{lcccccc} 
& \multicolumn{2}{c}{$\begin{array}{c}\text { Age 18-25 / } \\
\text { 18-25 lat }\end{array}$} & \multicolumn{2}{c}{$\begin{array}{c}\text { Age >25 / } \\
\text { >25 lat }\end{array}$} & Total/Ogótem \\
\cline { 2 - 8 } & $\mathbf{n}$ & $\%$ & $\mathbf{n}$ & $\%$ & $\mathbf{n}$ & $\%$ \\
\hline Yes/Tak & 5 & 10.2 & 13 & 29.5 & 18 & 19.4 \\
\hline No/Nie & 44 & 89.8 & 31 & 70.5 & 75 & 80.6 \\
\hline Total/Ogółem & 49 & 100.0 & 44 & 100.0 & 93 & 100.0 \\
\hline
\end{tabular}

*test $x^{2}(p=0.018)$ następujących odpowiedzi: akceptacja - 36,1\%, zrozumienie $-35,2 \%$, rozczarowanie $-13 \%$, złość $-8,3 \%$, odrzucenie $-7,4 \%$. Różnice nie były istotne statystycznie.

Wśród respondentów 80,6\% twierdziło, że bliscy nie „odwrócili się" od nich na wieść o ich orientacji homoseksualnej, zaś 19,4\% spotkało się z odwrotną reakcją.

Częściej bliscy „odwracali się” od osób w wieku powyżej 25 lat -29,5\% wobec 10,2\% bliskich, którzy odwrócili się od osób w wieku 18-25 lat. Wśród respondentów 89,8\% między 18. a 25. r.ż. oraz 70,5\% powyżej 25. r.ż. uznało, że bliscy nie „odwrócili się" od nich po ujawnieniu im orientacji homoseksualnej. Różnice były istotne statystycznie (tab. 3).

Pośród respondentów między 18. a 25. r.ż. 69,8\%, gdyby miało możliwość zmiany swojej orientacji homoseksualnej na heteroseksualną, nie zdecydowałoby się na to, 3,8\% dokonałoby tej zmiany, zaś $26,4 \%$ odpowiedziało, że nie wie. W grupie badanych powyżej 25. r.ż. 48,9\% nie skorzystałoby z takiej możliwości, 19,1\% odpowiedziało odwrotnie, natomiast 31,9\% stwierdziło, że nie wie. Różnice były istotne statystycznie (tab. 4).

Spośród ankietowanych $57,1 \%$ odpowiedziało, że miało kontakt seksualny z osobą płci przeciwnej, zaś 42,9\%, udzieliło odpowiedzi „nie”. Różnice pod względem płci i wieku nie były istotne statystycznie (tab. 5).

Respondenci odpowiedzieli, że najczęściej poznawali inne osoby homoseksualne za pomocą internetu - 31,1\%. Drugą w kolejności drogę kontaktu stanowili znajomi - 28,8\%, a następną pub - 25,1\%. Najrzadszą odpowiedzią wśród ankietowanych były ogłoszenia $-8,2 \%$ i inne $-6,7 \%$. Pytani przy tej ostatniej odpowiedzi wymieniali pracę i dworzec. Różnice pod względem wieku i płci nie były istotne statystycznie.

Ponad połowa - 55\% ankietowanych - odpowiedziała, że pracodawca nie musi wiedzieć o orientacji homoseksualnej swoich pracowników, 25\% respondentów nie miało zdania,

TABLE 4. Desire to change one's sexual orientation to heterosexual by respondents of particular age groups

TABELA 4. Zmiana orientacji na heteroseksualną przez badanych w poszczególnych grupach wiekowych

\begin{tabular}{lcccccc} 
& \multicolumn{2}{c}{$\begin{array}{c}\text { Age 18-25 / } \\
\text { 18-25 lat }\end{array}$} & \multicolumn{2}{c}{ Age $>\mathbf{2 5}$ / $>\mathbf{2 5}$ lat } & \multicolumn{2}{c}{ Total/Ogółem } \\
\cline { 2 - 8 } & $\mathbf{n}$ & $\%$ & $\mathbf{n}$ & $\%$ & $\mathbf{n}$ & $\%$ \\
\hline Yes/Tak & 2 & 3.8 & 9 & 19.1 & 11 & 11.0 \\
\hline No/Nie & 37 & 69.8 & 23 & 48.9 & 60 & 60.0 \\
\hline $\begin{array}{l}\text { I do not know / } \\
\text { Nie wiem }\end{array}$ & 14 & 26.4 & 15 & 31.9 & 29 & 29.0 \\
\hline Total/Ogółem & 53 & 100.0 & 47 & 100.0 & 100 & 100.0 \\
\hline
\end{tabular}

* test $\chi^{2}(p=0.024)$

TABLE 5. Answers of respondents to the question: "Have you ever had sexual contact with the opposite sex?"

TABELA 5. Odpowiedź badanych na pytanie: „Czy miałaś/-eś kiedykolwiek w życiu kontakt seksualny z osobą płci przeciwnej?”

\begin{tabular}{lcc} 
& $\mathbf{n}$ & $\%$ \\
\hline Yes/Tak & 56 & 57.1 \\
\hline No/Nie & 42 & 42.9 \\
\hline Total/Ogółem & 98 & 100.0 \\
\hline
\end{tabular}


$17 \%$ said that the employer should know about the sexual orientation of his/her employees. In group of the respondents $3 \%$ said that it depends on the type of employment and "how casual the work atmosphere is. If friendly relationships are also maintained, then it should be normal for a homosexual person to be able to talk about his/her private life without fear". In answer to the question: "Do you think that your employer would change his/her opinion about you or "approach" towards you if he/she knew about your sexual orientation?" $34 \%$ of respondents between aged 18-25 indicated the answer "I don't know". The same number of respondents $-28.3 \%$, in this age bracket, answered the question with a negative or marked the answer "partly", and 9.4\% felt that their employer would change their mind about them. Among respondents in the over 25 age group $42.6 \%$ answered in the negative, while $29.8 \%$ answered in the affirmative, $14.9 \%$ marked the answer "partly" and $12.8 \%$ "I don't know". The differences were statistically significant (Tab. 6).

In group of respondents $62 \%$ avoid situations that are dangerous to their own health and practice "safe sex", $28 \%$ occasionally practice "safe sex", while $10 \%$ did not. Differences in sex and age were not statistically significant.

On the question asking which diseases are sexually transmitted, the respondents replied as follows: $56 \%$ indicated AIDS, syphilis and gonorrhea, 27.4\% scabies and trichomoniasis, $16 \%$ condylomata acuminata and bacterial dysentery, $0.6 \%$ meningitis.

Knowledge about sexually transmitted diseases was most often obtained through the Internet (30\% of respondents). Sex educatin in school was ranked second $-24.7 \%$. Further sources of information included: books $-21.3 \%$, friends $12.2 \%$, parents $-10.3 \%$, while $1.5 \%$ of respondents said they did not know. The differences in terms of age and sex were not statistically significant.

The legalization of homosexual partnership in Poland was supported by $84 \%$ of respondents, $7 \%$ of respondents were against, and $9 \%$ of respondents did not express their opinion. The differences in terms of age and sex were not statistically significant.

TABLE 6. Answers of respondents, depending on their age, to the question: "Do you think that your employer would change his/her opinion about you or "approach" to you if he/she knew about your sexual orientation?" TABELA 6. Odpowiedź respondentów w zależności od wieku na pytanie: "Czy uważasz, że pracodawca zmieniłby zdanie o Tobie / „podejście" do Ciebie, gdyby wiedziat o Twojej orientacji seksualnej?"

\begin{tabular}{lcccccc} 
& $\begin{array}{c}\text { Age 18-25 / } \\
\text { 18-25 lat }\end{array}$ & \multicolumn{2}{c}{ Age $>$ 25 / $>$ 25 lat } & \multicolumn{2}{c}{ Total/Ogółem } \\
\cline { 2 - 8 } & $\mathbf{n}$ & $\%$ & $\mathbf{n}$ & $\%$ & $\mathbf{n}$ & $\%$ \\
\hline Yes/Tak & 5 & 9.4 & 14 & 29.8 & 19 & 19.0 \\
\hline No/Nie & 15 & 28.3 & 20 & 42.6 & 35 & 35.0 \\
\hline $\begin{array}{l}\text { Partially/ } \\
\text { Częściowo }\end{array}$ & 15 & 28.3 & 7 & 14.9 & 22 & 22.0 \\
\hline $\begin{array}{l}\text { I don't know / } \\
\text { Nie wiem }\end{array}$ & 18 & 34.0 & 6 & 12.8 & 24 & 24.0 \\
\hline \begin{tabular}{l} 
Total/Ogółem \\
\hline
\end{tabular} & 53 & 100.0 & 47 & 100.0 & 100 & 100.0 \\
\hline
\end{tabular}

* test $x^{2}(p=0.003)$ zaś 17\% uznało, że pracodawca powinien wiedzieć. Pozostałe $3 \%$ respondentów stwierdziło, że zależy to od wykonywanej pracy oraz „od tego jak luźna jest atmosfera pracy; jeżeli są utrzymywane również stosunki koleżeńskie, powinno być to normalne, że osoba homoseksualna może mówić o swoim życiu prywatnym bez strachu”.

Na postawione pytanie: „Czy uważasz, że pracodawca zmieniłby zdanie o Tobie/„podejście” do Ciebie, gdyby wiedział o Twojej orientacji seksualnej?” wśród ankietowanych między 18. a 25. r.ż. 34\% zaznaczyło odpowiedź „nie wiem”, 28,3\% odpowiedziało przecząco bądź zaznaczyło odpowiedź „częściowo", a 9,4\% odpowiedziało twierdząco. W grupie wiekowej powyżej 25 lat 42,6\% respondentów odpowiedziało przecząco na powyższe pytanie, 29,8\% uznało, że pracodawca zmieniłby o nich zdanie, 14,9\% zaznaczyło odpowiedź „częściowo”, a 12,8\% „nie wiem”. Różnice były istotne statystycznie (tab. 6).

Unikanie sytuacji stanowiących zagrożenie dla własnego zdrowia oraz uprawianie „bezpiecznego seksu” zadeklarowało $62 \%$ badanych, $28 \%$ robi to czasami, natomiast $10 \%$ wcale. Różnice pod względem płci i wieku nie były istotne statystycznie.

Na pytanie, które choroby są przenoszone drogą płciową, respondenci odpowiedzieli: 56\% - AIDS, kiła i rzeżączka, 27,4\% świerzb i rzęsistkowica, 16\% - kłykciny kończyste i czerwonka bakteryjna, 0,6\% - zapalenie opon mózgowych.

Wiedzę na temat chorób przenoszonych drogą płciową ankietowani najczęściej zdobywali za pomocą internetu $30 \%$ odpowiedzi. Na drugim miejscu uplasowała się szkoła - 24,7\%. Na dalszych pozycjach znalazły się: książki - 21,3\%, znajomi $-12,2 \%$, rodzice $-10,3 \%$, natomiast $1,5 \%$ respondentów odpowiedziało, że nie wie. Różnice pod względem wieku i płci badanych nie były istotne statystycznie.

Legalizację związków partnerskich w Polsce poparło $84 \%$ respondentów, przeciw było $7 \%$ ankietowanych, a swojego zdania nie wyraziło 9\%. Różnice pod względem wieku i płci badanych nie były istotne statystycznie.

Wśród ankietowanych stosunek do wychowywania dzieci przez parę osób tej samej płci przedstawiał się następująco: $54 \%$ nie widziało przeciwwskazań, $21 \%$ nie miało zdania, $16 \%$ uznało, że to powinno być zakazane, $9 \%$ stwierdziło, że takie prawo powinny mieć tylko pary kobiet. Żaden z ankietowanych nie stwierdził, że dziecko powinno być wychowywane tylko przez parę mężczyzn. Różnice pod względem płci i wieku badanych nie były istotne statystycznie (tab. 7).

TABLE 7. Attitude of respondents to the raising of children by a homosexual couple

TABELA 7. Stosunek badanych do wychowywania dzieci przez parę homoseksualną

\begin{tabular}{lcc} 
& $\mathbf{n}$ & $\%$ \\
\hline No contraindications / Brak przeciwwskazań & 54 & 54.0 \\
\hline They should not / Nie powinny & 16 & 16.0 \\
\hline Only lesbian couples / Tylko kobiety & 9 & 9.0 \\
\hline Only gay couples / Tylko mężczyźni & 0 & 0.0 \\
\hline I have no opinion / Nie mam zdania & 21 & 21.0 \\
\hline Total/Ogółem & 100 & 100.0 \\
\hline
\end{tabular}


Among the respondents, the attitude towards the raising of children by a same-sex couple is as follows: $54 \%$ had no contraindications, $21 \%$ had no opinion, $16 \%$ were opposed, and $9 \%$ stated that only by a lesbian couple. None of the respondents stated that a child should be brought up only by a male pair. The differences in terms of sex and age were not statistically significant (Tab. 7).

In the future, $38.8 \%$ of respondents plan to adopt a child should it be legally possible to do so, $37.2 \%$ would like for their partnership to be legally confirmed, $11.6 \%$ did not have such intention, $10.7 \%$ do not want a long-term relationship, and $1.7 \%$ of respondents chose the answer: for women, obtaining sperm from a sperm bank in the case of a desire to have a child.

In the group of respondents $40 \%$ would permanently leave Poland to be able to enter into a legal partnership in another country, 39\% would not take advantage of this option, and $21 \%$ of respondents have no opinion on this topic. Differences in age and sex were not statistically significant.

The occurrence of homophobia in Polish society was confirmed by $75 \%$ of the respondents, its absence was indicated by $14 \%$, while $11 \%$ did not have an opinion on this topic. The differences in terms of age and sex were not statistically significant (Tab. 8).

\section{DISCUSSION}

The polls conducted in 2001 among gay, lesbian, bisexual, and transgender people in the "Report on discrimination as a result of sexual orientation" by the Lambda Association showed that $51 \%$ of interviewed persons had revealed their sexual orientation to their families, while $72 \%$ did so to their friends [4]. In addition, the survey conducted by Savin-Williams, which included almost 2000 young people representing sexual minorities, stated that they more willingly reveal their sexual orientation to friends $-76 \%$ - rather than to their mother $-49 \%$, brother or sister $-38 \%$, or father $-36 \%$ [5]. Likewise in my research, people of non-heterosexual orientation most often reveal their sexual orientation to their friends rather than families. Accordingly, 33.9\% of people revealed their homosexual orientation to their friends and $22.8 \%$ did so to their parents.

The report "Gays and lesbians in the workplace" mentions that $58 \%$ of respondents did not hide their sexual orientation in the workplace [6]. Conversely, in my research, only $16.1 \%$ of the respondents have publicized their sexual orientation in the workplace.

Research on the analysis of sexual attitudes and behaviors of medical students has shown that $5 \%$ of women and $9 \%$ of men consider homosexuality to be a disease [7]. In my research, 1 of the 100 people polled stated that homosexuality is a disease, $75 \%$ that it is a inherited trait, $18.5 \%$ that is a acquired trait, and 5.6\% had marked the answer "other".

Data from the United States from the year 1970 concerning the beginning of homosexual feelings indicates that it occurred for $33 \%$ of men and $17 \%$ of women before the age
W przypadku pytania o potomstwo w przyszłości 38,8\% respondentów odpowiedziało, że planowało adopcję w miarę możliwości prawnych, zaś 1,7\% respondentów wskazało możliwość skorzystania z banku spermy w przypadku chcących mieć dzieci kobiet.

Na pytanie o prawne potwierdzenie związku partnerskiego respondenci odpowiadali następująco: $37,2 \%$ chciałoby skorzystać z takiej możliwości, 11,6\% nie miało takiego zamiaru, 10,7\% nie chciało dłuższego związku.

W przypadku pytania o możliwość wyjechania na stałe z Polski w celu zawarcia związku partnerskiego 40\% respondentów odpowiedziało, że zdecydowałoby się na to, 39\% nie skorzystałoby z możliwości, a 21\% nie miało zdania na ten temat. Różnice pod względem wieku i płci nie były istotne statystycznie.

Występowanie zjawiska homofobii w polskim społeczeństwie potwierdziło $75 \%$ ankietowanych, jego brak wskazało $14 \%$, natomiast $11 \%$ nie miało na ten temat zdania. Różnice pod względem wieku i płci badanych nie były istotne statystycznie (tab. 8).

\section{DYSKUSJA}

Stowarzyszenie Lambda w „Raporcie o dyskryminacji ze względu na orientację seksualną” w badaniach przeprowadzonych wśród gejów, lesbijek, osób biseksualnych i transseksualnych stwierdziło, że 51\% osób ujawniło swoją orientację seksualną rodzinie, a 72\% przyjaciołom [4]. Również sondaż wspomniany przez Savin-Williams, w którym wzięło udział niemal 2 tys. młodych osób reprezentujących mniejszości seksualne, wskazuje, że orientacja chętniej ujawniana jest przyjaciołom - 76\% - niż matce - 49\%, bratu lub siostrze - 38\% - czy ojcu -36\% [5]. W badaniach Agnieszki Licow osoby orientacji nieheteroseksualnej także częściej ujawniają się przyjaciołom niż rodzinie - odpowiednio 33,9\% oraz $22,8 \%$.

Z raportu „Geje i lesbijki w miejscu pracy” wynika, że 58\% ich respondentów nie ukrywało swojej orientacji seksualnej w pracy [6]. Z przeprowadzonych przez Licow badań wynika, że zaledwie $16,1 \%$ badanych ujawniło swoją orientację homoseksualną w pracy.

Badania na temat analizy postaw i zachowań seksualnych studentów medycyny ukazały, że aż 5\% kobiet i 9\% mężczyzn uważa homoseksualizm za chorobę [7]. W przedstawionych w artykule badaniach jedna ze 100 ankietowanych osób także stwierdziła, iż homoseksualizm jest chorobą, 75\%, że jest cechą wrodzoną, 18,5\% cechą nabytą, a 5,6\% zaznaczyło odpowiedź „inne”.

TABLE 8. Opinion of respondents on the occurrence of homophobia in Polish society

TABELA 8. Opinia respondentów na temat występowania zjawiska homofobii w polskim społeczeństwie

\begin{tabular}{lcc} 
& $\mathbf{n}$ & $\%$ \\
\hline Yes/Tak & 75 & 75.0 \\
\hline No/Nie & 14 & 14.0 \\
\hline I have no opinion / Nie mam zdania & 11 & 11.0 \\
\hline Total/Ogółem & 100 & 100.0 \\
\hline
\end{tabular}


of $13,52 \%$ and $22 \%$, respectively, before the age of $15,70 \%$ and $34 \%$ before the age of 17 , and $88 \%$ and $74 \%$ before the age of 21 [8]. In my research regarding the age at which one determines his or her own homosexual orientation, $68 \%$ of respondents stated that it occurred before 18 years of age, which is comparable to other data pertaining to the first sexual initiation. However, Majka-Rostek explains that in Polish society, the age of homosexual initiation might be higher than in American society [8].

In the Lambda Association's report on the question “Did you ever feel a need to hide or to be silent about your sexual orientation in the workplace?" $39 \%$ of people polled responded that indeed it was the situation in every workplace, and $34.5 \%$ stated that it was so only with certain jobs/ people [4]. In the research conducted by the Lambda in 2001, $75 \%$ of respondents stated that they hide their sexual orientation from people in the workplace. Furthermore, in research conducted during 2005 and 2006, the percentage of respondents hiding their sexuality at work was $84.6 \%$ [9]. My research found that $55 \%$ of respondents do not see the need for employers to be made aware of their sexual orientation and $35 \%$ stated that the employer would not change his/her attitude towards the employee even if they found out about their sexual orientation.

Research conducted by the Economic Association For Gays and Lesbians revealed that over half of respondents, $51 \%$ of those who are currently employed, stated that in their respective workplaces, a homosexual person would be treated the same as any other employee. Among the respondents $27 \%$ stated that a homosexual employee would be treated worse than the others [10]. The majority of participants in my research have similarly stated that the employer would not have changed his or her stance or attitude towards the employee if their homosexualiy were revealed, $19 \%$ of respondents stated the opposite.

Szurkowska, in her work on the importance of Internet chatting in the lives of homosexual people, stipulated that chats play a significant role in shaping homosexual identity. The research that she conducted among the users of a chat devoted to gays and lesbians found that for $65 \%$ of polled women and $63 \%$ of polled men the chat helped them to make contact with other people of a homosexual orientation [11]. My research has shown a similar result. The most common place to meet other homosexual people was the Internet $-31.1 \%$ of respondents. This answer was the most common irregardless of the age of respondents.

Szurkowska also writes that women are less likely to consider the Internet as the main place to meet other lesbians [11]. This agrees with the results of my research. For example, 30.7\% of women had met another homosexual person through the Internet, whereas for men it was 31.4\%.

In her paper, Szurkowska also includes information from research conducted in Warsaw in 1988 (i.e. pre widespread Internet use). That research found that over half of gay men $(62-88 \%)$ met other men of homosexual orientation in bars, restaurants, or cafes [11]. In my research, the pub is the third
Amerykańskie dane z 1970 r., dotyczące inicjacji homoseksualnej, wskazują, że przed ukończeniem: 13 r.ż. dotyczyła ona 33\% mężczyzn i 17\% kobiet, 15 r.ż. kolejno 52\% i 22\%, 17 r.ż. - 70\% i 34\%, a 21 r.ż. - 88\% i 74\% [8]. W przedstawionych badaniach Licow, na pytanie o wiek określenia swojej orientacji homoseksualnej, $68 \%$ respondentów odpowiedziało, że było to przed ich 18. r.ż., a więc - porównując to z wynikami odnoszącymi się do pierwszej inicjacji seksualnej - zależności te są do siebie podobne. Jednakże Majka-Rostek pisze, że w warunkach polskich możemy podejrzewać, iż wiek inicjacji homoseksualnej może być wyższy niż u społeczeństwa amerykańskiego [8].

W raporcie Stowarzyszenia Lambda na pytanie: „Czy kiedykolwiek czułeś/-aś potrzebę ukrywania lub milczenia na temat swojej orientacji w miejscu pracy?" 39\% ankietowanych odpowiedziało, że tak, w każdej pracy, a 34,5\% tylko w niektórych pracach. Ponadto $39 \%$ respondentów stwierdziło, że musi ukrywać swoją orientację seksualną przed wszystkimi w pracy, a 31\% przed niektórymi osobami [4]. W badaniu Lambdy z 2001 r. 75\% respondentów stwierdziło, że ukrywa swoją orientację seksualną w pracy, zaś w badaniu dotyczącym lat 2005 i 2006 procent respondentów wyniósł już 84,6 [9]. Z przeprowadzonych przez Agnieszkę Licow badań wynika, że 55\% respondentów nie widzi konieczności, dla których pracodawca powinien wiedzieć o ich orientacji seksualnej, a 35\% uznało, że pracodawca nie zmieniłby o nich zdania przez pryzmat ich orientacji seksualnej.

Badania przeprowadzone przez Towarzystwo Ekonomiczne na Rzecz Gejów i Lesbijek ukazały, że ponad połowa respondentów - 51\% - którzy są aktywni zawodowo twierdzi, że w ich zakładzie pracy osoba o orientacji homoseksualnej byłaby traktowana tak samo jak inni pracownicy, a więcej niż jedna czwarta - 27\% - ocenia, że gorzej od innych [10]. Respondenci biorący udział w badaniach Licow podobnie stwierdzili, że pracodawca nie zmieniłby o nich zdania z powodu orientacji homoseksualnej, tylko 19\% badanych uważało odwrotnie.

Barbara Szurkowska, w swojej pracy na temat roli czatu w życiu osób zorientowanych homoseksualnie, twierdziła, że ogrywa on ogromną rolę w kształtowaniu tożsamości homoseksualnej. Przeprowadzając badanie wśród użytkowników czatu dla gejów i lesbijek, uznała, że dla 65\% badanych kobiet i 63\% mężczyzn był on pomocny w nawiązywaniu kontaktów z osobami orientacji homoseksualnej [11]. Z badań Licow również wynika, że najczęstszym miejscem poznania innych osób orientacji homoseksualnej jest internet -31,1\%. Odpowiedź ta padała najczęściej, bez względu na wiek respondentów.

Szurkowska pisała również, że dla kobiet internet ma mniejsze znaczenie w poznaniu osób o tej samej orientacji seksualnej niż w przypadku mężczyzn [11]. Przedstawione w artykule badania również wykazały tę zależność - 30,7\% kobiet poznało drugą osobę homoseksualną za pomocą internetu, a w przypadku mężczyzn było to $31,4 \%$.

W pracy na temat roli czatu w życiu osób zorientowanych homoseksualnie odnajdujemy również informacje na temat badań przeprowadzonych w Warszawie w 1988 r. Wynikało z nich, że ponad połowa gejów (62-68\%) poznała innych mężczyzn orientacji homoseksualnej w barach, kawiarniach lub 
most common answer in terms of places to meet homosexual persons, chosen by $25.1 \%$ of respondents $-25.7 \%$ of men and $24.4 \%$ of women. According to research conducted by Krzemiński, $86 \%$ of gays and lesbians would prefer for samesex partnerships to be legalized in Poland; $74 \%$ would like to be able to marry, and $41 \%$ support the adoption of children by homosexual couples [12]. My research revealed a similar situation $-84 \%$ of respondents are for the legalization of samesex partnerships in Poland.

The creators of the website www.lesmama.republika.pl published the results of a poll on the subject of alternative parenthood. Of over 319 lesbians participating in the poll, $47 \%$ plan on becoming a mother, while $35 \%$ of gay men plan on becoming fathers [6]. My research has found that $43.3 \%$ of women and $34.4 \%$ of men want to adopt a child in the future if the laws would allow them to do so.

The research presented in the "Report on Discrimination" states that the adoption of children by homosexual couples is supported by only $33 \%$ of gays, while $57 \%$ are against it [4]. This is contrary to my research, which has shown that $59.2 \%$ of polled men do not see any negatives in the upbringing of children by homosexual couples. Only $18.4 \%$ of the male respondents stated otherwise.

In the Lambda Association's report, a poll was conducted among gay, lesbian, bisexual, and transexual people on the question of their desire to emigrate from Poland, and $49 \%$ of respondents confirmed their desire to leave Poland, $63 \%$ of polled people cited their sexual orientation as a reason for their desire to emigrate. On a similar question in my research, $40 \%$ of respondents expressed the desire to emigrate from Poland due to the ability to marry in other countries.

The report "Violence motivated by homophobia" from the year 2011 confirmed that for $78 \%$ of respondents the most common vulgarities directed towards them are those related to their homosexual orientation [13]. In turn, Szurkowska stipulated in her research that over $84 \%$ of women and $77 \%$ of men find that the attitudes of the majority of society towards homosexual people can be characterized as slightly or decisively hostile [11]. In the report "The social situation of bisexual and homosexual people in Poland", $84 \%$ of the people polled stated that homosexual people in Poland are not tolerated nor accepted. Only $13.2 \%$ of those polled stated otherwise [14]. However, according to surveys conducted among medical students concerning attitudes and behaviors towards homosexuality, there is a dominating acceptance of homosexuality or tolerance of it in spite of the lack of acceptance [7]. In agreement with the 2011 report, $75 \%$ of respondents of my study believe that homophobia is prevalent within Polish society.

Szukalski points out that it would be highly interesting to learn about the faction of homosexual people who accept their sexual orientation, especially among the number of people who are still "coming out of the closet". However, there arises a notion that in the reality of living in Poland such questions are considered difficult and discriminatory [8]. My research has shown that $85 \%$ of respondents do accept their homosexual orientation and $78 \%$ of them have revealed it. restauracjach [11]. W badaniach własnych przedstawionych w artykule pub jest trzecią najczęstszą odpowiedzią co do miejsca poznania osób homoseksualnych. Przy tej odpowiedzi plasowało się 25,1\% badanych, a zależność wg płci jest następująca: 25,7\% mężczyzn oraz 24,4\% kobiet.

Jak wynika z badań przeprowadzonych pod kierunkiem Krzemińskiego, 86\% gejów i lesbijek chciałoby wprowadzenia w Polsce związków partnerskich, 74\% chciałoby mieć możliwość zawierania małżeństwa, a $41 \%$ popiera adopcję dzieci przez pary homoseksualne [12]. Badania Licow ujawniły podobną zależność, $84 \%$ respondentów jest za legalizacją związków partnerskich w Polsce.

Autorzy portalu internetowego http://www.lesmama.republika.pl zamieścili wyniki ankiety na temat alternatywnego rodzicielstwa. Spośród 319 biorących w niej udział lesbijek $47 \%$ planuje zostać matkami, zaś 35\% gejów ojcami [6]. Badania, które przedstawiono powyżej, oznaczają że 43,3\% kobiet i 34,4\% mężczyzn homoseksualnych chciałoby w przyszłości adoptować dziecko w miarę możliwości prawnych.

Badania przedstawione w „Raporcie o dyskryminacji” świadczą, że adopcję poparło zaledwie 33\% gejów, a 57\% jest jej przeciwna [4]. Badania Licow wskazały przeciwną zależność, a więc $59,2 \%$ badanych mężczyzn nie widzi przeciwwskazań w związku z wychowywaniem dzieci przez parę homoseksualną, a tylko 18,4\% respondentów płci męskiej uważa odwrotnie.

W raporcie Stowarzyszenia Lambda zapytano ankietowanych gejów, lesbijki, osoby biseksualne i transseksualne o chęć emigracji z Polski. Zdeklarowało ją 49\% respondentów, zaś $63 \%$ z nich jako powód podało swoją orientację seksualną.

Na podobne pytanie zadane przez Licow chęć wyjazdu na stałe z Polski ze względu na możliwość zawierania związków małżeńskich w innych państwach wyraziło 40\% respondentów.

Raport „Przemoc motywowana homofobią” z 2011 r. dowiódł, iż wg 78\% ankietowanych najczęstsze obraźliwe wypowiedzi dotyczą orientacji homoseksualnej [13]. Z kolei w badaniach Szurkowskiej aż 84\% kobiet i 77\% mężczyzn uznało, że odczucia większości społeczeństwa wobec osób homoseksualnych są raczej lub zdecydowanie wrogie [11]. Raport „Sytuacja społeczna osób biseksualnych i homoseksualnych w Polsce” ukazuje, że $84 \%$ ankietowanych stwierdziło, że osoby homoseksualne w Polsce nie są akceptowane i szanowane. Jedynie 13,2\% badanych twierdziło odwrotnie [14]. Jednakże wg badań w zakresie postaw wobec homoseksualizmu przeprowadzonych wśród studentów medycyny dominuje akceptacja bądź poszanowanie braku akceptacji [7]. Z grupy badawczej Licow $75 \%$ respondentów uważa, że w polskim społeczeństwie występuje zjawisko homofobii.

Piotr Szukalski zauważa, że niezwykle interesująca byłaby znajomość frakcji homoseksualistów, którzy akceptują swoją orientację seksualną, a zwłaszcza liczby osób ujawniających się. Jednakże w tym przypadku pojawia się stwierdzenie, że w polskich realiach kwestie te są drażliwe i określane jako dyskryminujące [8]. Na podstawie badań własnych wykazano, że 85\% respondentów akceptuje swoją orientację homoseksualną oraz $78 \%$ z nich ujawniło ją. 


\section{CONCLUSIONS}

1. Most lesbians and gays define their sexual orientation before the age of 18 .

2. Acceptance and empathy are the most common reactions to people of homosexual orientation "coming out".

3. Homosexual people accept their sexual orientation and do not hide this fact. They are happy to talk about it (to friends, acquaintances, parents) outside of their workplace.

4. The places in which people of homosexual orientation get to know each other are dependent on the age and the sex of the subjects.

5. Homosexual people believe that there is no need for employers to know about the homosexual orientation of their employees.

6. Lesbians and gays are aware of sexually transmitted diseases.

7. Homosexual people support the legalization of samesex partnerships in Poland, and in the future, plan to enter into legally confirmed partnerships and to pursue the adoption of a child.
1. Większość lesbijek i gejów określa swoją orientację seksualną przed 18. r.ż.

2. Akceptacja i zrozumienie są najczęstszą reakcją na ujawnienie się ludzi o orientacji homoseksualnej.

3. Osoby homoseksualne akceptują swoją orientację seksualną i chętnie ją ujawniają wszędzie (przyjaciele, znajomi, rodzice), poza swoją pracą.

4. Źródła poznania innych osób o orientacji homoseksualnej zależne są od wieku i płci badanych.

5. Osoby homoseksualne uważają, że nie ma konieczności informowania pracodawcy o orientacji homoseksualnej pracowników.

6. Lesbijki i geje są świadomi chorób przenoszonych drogą płciową.

7. Osoby orientacji homoseksualnej popierają legalizację związków partnerskich w Polsce, a w przyszłości planują zawarcie związku partnerskiego potwierdzonego prawnie oraz adopcję dziecka.

\section{REFERENCES / PIŚMIENNICTWO}

1. Jodko A, editor. Tabu seksuologii: wątpliwości, trudne tematy, dylematy w seksuologii i edukacji seksualnej. Warszawa: Wydaw. Szkoły Wyższej Psychologii Społecznej „Academica”; 2008.

2. Iniewicz G. Społeczno-kulturowy kontekst terapii osób o homoseksualnej orientacji. Psychiatr Pol 2009;43(1):87.

3. Zdrowie reprodukcyjne. Wikipedia. http://pl.wikipedia.org/wiki/Zdrowie_reprodukcyjne (dostęp: 26.05.2012).

4. Stowarzyszenie Lambda. Raport o dyskryminacji ze względu na orientację seksualną w Polsce. Warszawa; 2001. http://lambdawarszawa. org/wp-content/uploads/2015/08/Raport_dyskryminacja_2000_p. pdf (dostęp: 23.06.2012).

5. Savin-Wiliams TC. Homoseksualność w rodzinie. Ujawnienie tajemnicy. Sopot: Gdańskie Wydaw. Psychologiczne; 2011.

6. Majka-Rostek D. Związki homoseksualne. Studium socjologiczne. Warszawa: Wydaw. Centrum Doradztwa i Informacji; 2008.

7. Cubała WJ, Grabowski K, Wichowicz H. Analiza postaw i zachowań seksualnych studentów medycyny. Ann Acad Med Gedan 2004;34:66.
8. Slany K, Kowalska B, Śmietana M. Homoseksualizm: perspektywa interdyscyplinarna. Kraków: Zakład Wydawniczy Nomos; 2005.

9. Śmiszek K. Dyskryminacja ze względu na orientację seksualną i tożsamość płciową w zatrudnieniu. Warszawa: Wydaw. Kampania Przeciw Homofobii; 2011.

10. Centrum Badania Opinii Społecznej: Postawy wobec gejów i lesbijek. Warszawa; 2010. https://www.cbos.pl/SPISKOM.POL/2010/K_095_10. PDF (dostęp: 9.07.2012).

11. Szurkowska B. Rola czata w życiu osób zorientowanych homoseksualnie - badania wśród społeczności internetowej. Seksuol Pol 2004;2:42-49.

12. Zima M. Tęczowe rodziny w Polsce. Prawo a rodziny lesbijskie i gejowskie. Raport 2009. Warszawa: Wydaw. Kampania Przeciw Homofobii; 2010.

13. Makuchowska M. Przemoc motywowana homofobią. Raport 2011. Warszawa: Wydaw. Kampania Przeciw Homofobii; 2011.

14. Abramowicz M. Sytuacja społeczna osób biseksualnych i homoseksualnych w Polsce. Raport za lata 2005 i 2006. Warszawa: Wydaw. Kampania Przeciw Homofobii; 2008. 